\title{
Gender Responsive and Child Sensitive Disaster Management in Pakistan
}

\author{
Aliya Khalid a , Syed Salman Hassan ${ }^{\text {b }}$, Syeda Mahnaz Hassan ${ }^{\text {c }}$, Muhammad Adnan ${ }^{\text {d }}$ \\ ${ }^{a}$ Assistant Professor, Department of Social Work, University of the Punjab, Pakistan. \\ ${ }^{\mathrm{b}}$ Deputy Director ORIC, Virtual University of Pakistan. \\ ${ }^{c}$ Chairperson, Department of Social Work, University of the Punjab, Lahore, Pakistan. \\ Email: drsyedamahnazhassan@gmail.com \\ d MPhil Scholar, Department of Social Work, University of the Punjab, Lahore, Pakistan.
}

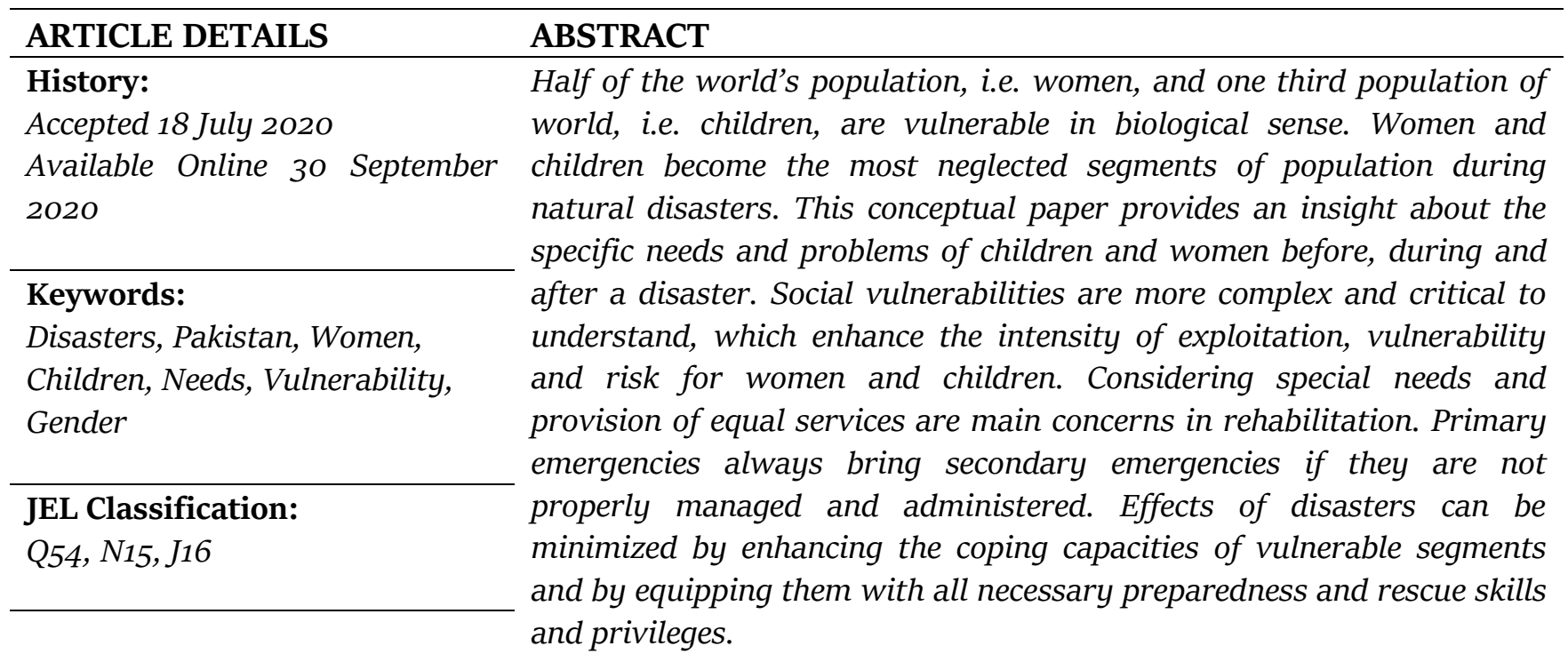

DOI: $10.47067 /$ reads.v6i3.262

(C) 2020 The authors. Published by SPCRD Global Publishing. This is an open access article under the Creative Commons Attribution-

NonCommercial 4.0

Corresponding author's email address: drsyedamahnazhassan@gmail.com

\section{Introduction}

According to the International Federation of Red Cross and Red Crescent Societies disasters are hasty, catastrophic, and destructive occurrences that disturb the normal functioning of a community and society and bring more people to vulnerability. Disasters are caused by natural as well as human causes and result in havoc in personal as well as in public life and great loss of lives, property and infrastructure turn the life on a new track (Random House Kernerman Webster's College Dictionary). A disaster can be understood as a natural or man-made calamity which brings sudden destruction of infrastructure, loss of lives and environmental, social and economic problems. Figure-1 and Figure-2 in the appendix showed the time trend of reported natural disasters from 1975 to 2007 and the percentage of people killed by natural disaster. 


\section{Time trend of reported \\ natural disasters, $1975-2007$}

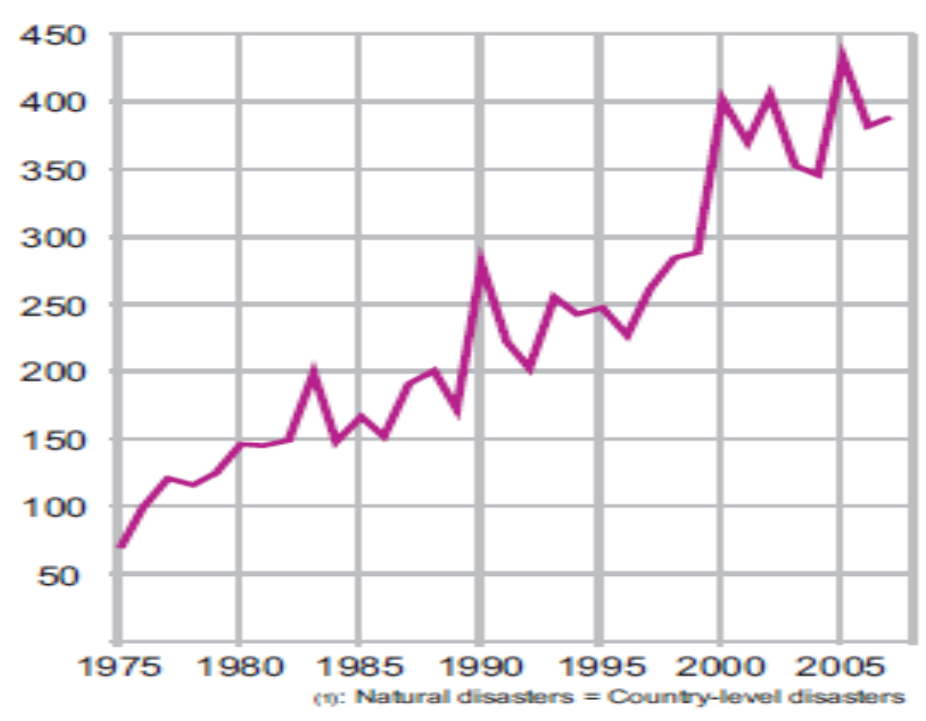

Figure-1: (Source: EM-DAT: THE OFDA/CRED International Data base-2008)
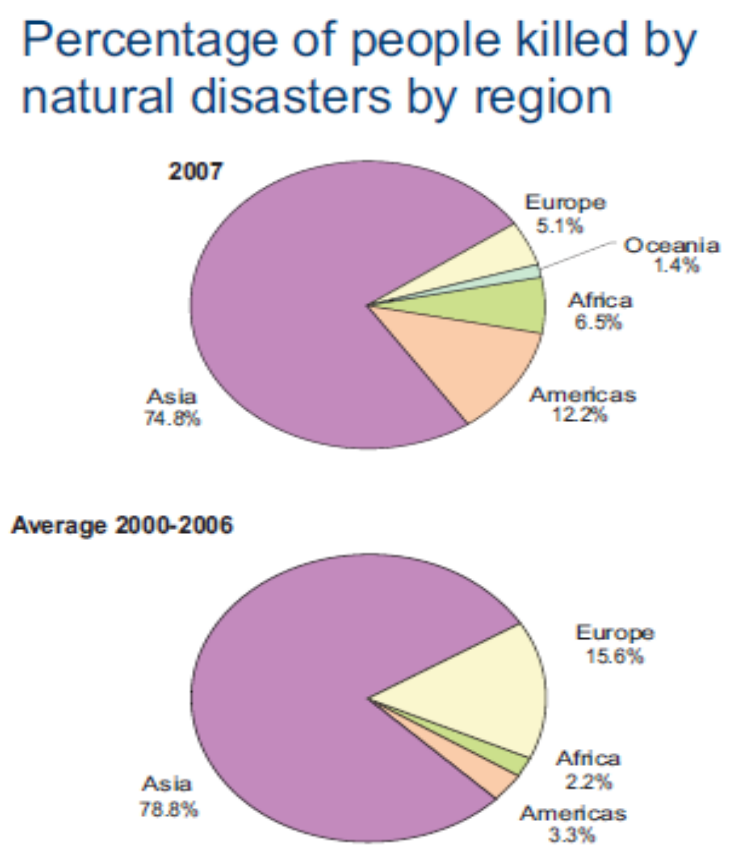

Figure-2: (Source: EM-DAT: THE OFDA/CRED International Data base-20o8)

A series of repeated large-scale disasters were experienced in Pakistan during the last decade. Floods have become yearly phenomenon due to hot climate of the country, while a number of earthquake shocks have been observed during 2015 and 2016. Our geography \& climatic conditions make us quite vulnerable to disasters. 
Review of Economics and Development Studies, Vol. 6 (3) 2020, 727-738

Effects of disasters are more pronounced on vulnerable groups i.e. women, children, old and people with disabilities. Women and children are always at weak position by access, opportunities, movement, decision making, power relations and benefits even in normal circumstances.

\section{Vulnerabilities are Socially Constructed:}

The social, physical and economic factors which enhance the susceptibility of individuals or groups of individuals regarding the impacts of hazards and disasters are called vulnerabilities. Most of vulnerabilities that people face in natural disasters are related with social and cultural realities i.e. power relationship, opportunities, benefits, resources, location, capacities, wealth, health, knowledge, freedom to get information and movement and gender and class differences. Vulnerabilities are now viewed as contextually driven i.e. socially constructed situations by which some segments of population are discouraged or restricted to participate in empowering activities by utilizing their capacities.

Vulnerabilities are of different kinds ranging from economic, social, religious, physical and environmental factors. The most deeply rooted and neglected once are social vulnerabilities, which have become part of our cultural system now. Poor, marginalized people and women due to gender differences always have less access to resources and opportunities resulting in their weak coping capacity against disasters. This socially constructed vulnerability hinders their participation in information seeking, movement, preparedness, training and coping skills. These susceptibilities enhance their vulnerabilities in disasters.

\section{Historical perspective of Inclusion of Women \& Children in Policy:}

Vulnerable groups were identified as "Response Focused" for the first time with the emergence of Hyogo Framework of Action 2005-15; (Building the Resilience of Nations and Communities to disasters, is a 10 years global pact, agreed in 2005 by nearly 170 governments, including Pakistan) which outlines the steps to reduce disaster impacts and improve country's ability to respond and recover from disasters.

Vulnerable segments of population are more vulnerable to disasters, having their special needs and limitations. Inadequate preparation with no consideration of the needs of vulnerable population often leads to disastrous consequences i.e. large death toll as in Hurricane Katrine, Tsunami and 2010 and 2014 floods of Pakistan. Vulnerable people, also called "special needs" people or "at-risk" people, can be distinguished as those that are particularly at menace of weak economic, physical or social health, during and after a disaster. They have excessive needs of food, mobility, survival, medical aid and supervisory care in overall spectrum of disaster.

\section{Women's Vulnerability:}

Total female population in Pakistan was reported at $48.54 \%$ in 2019 (World Bank, 2020). Women are known to be affected adversely by disasters. Their vulnerability and risk are not only on account of their biological make up and specific needs, but are also on account of their disadvantaged position within the society and their limited access to information and resources that result in restricted capacities and coping strategies.

They are often poorer than men and are less aware and mobile due to cultural reasons. Their role as caregivers and protectors during disasters increases as an additional burden on their personal coping capacities. Besides, they are prone to physical violence, sexual assaults, trafficking, and exploitation. Women are also disregarded in planning of Disaster Risk Reduction policy and their opinion and needs remain overlooked. They need special attention in evacuation, in services provided, 
Review of Economics and Development Studies, Vol. 6 (3) 2020, 727-738

in shelters homes, in food requirements and in overall living atmosphere in relief camps after disaster.

\section{Children's Vulnerability:}

According to the report of UN Economic and Social Affairs Department and Country Meters, there are $35.4 \%$ people under the age of 15 years in Pakistan.

Children form a large part of the affected population and therefore, special measures are sought to protect them from harm and ensure their access to basic services. This refers to both boys and girls. Children tend to suffer on account of malnutrition, exploitation, kidnapping, and sexual violence in disasters amongst other factors that are psychological fears, food needs and basic requirement of health environment. Their position becomes further vulnerable due to their inability to share their experiences and to participate in decision making affecting their lives. Specific needs and growth patterns make them vulnerable to others.

Some women remain restricted in evacuation process because of their socially constructed responsibility of caregivers to elderly, children, disabled and sick persons of their family. Women have practically no information or practice of climbing and swimming. Social and cultural system and norms of society dictate that these are not 'womanly' activities. Therefore, during all major disasters i.e. floods and earthquake, women were unable to evacuate from the situation that always resulted in huge number of women deaths. WHO report indicates that in Indian Ocean Tsunami of 2004, 80\% deaths were of women. WHO report also indicates that women and children are $75 \%$ more vulnerable in disasters as compared to male population. Beside the direct effects of disaster, women are also prone to health issues, sexual health, reproductive health and violence problems. According to Enarson (2000), “Women's work is heavily impacted by disasters, and their economic losses can be extensive. For those whose income is based on homework, the loss of housing often means the loss of workspace, tools, equipment, inventory, supplies and markets. Domestic violence appears to increase when men's sense of control is diminished in disasters."

Akcar, Gopalan and Yonder (2012) stated, “Disasters upsurge women's domestic and care-giving work intensely. It also discounts the women needs which are not from male headed households. Their economic role and recovery is also ignored. These prejudices damage the overall recovery cycle of any community. Gender sensitive recovery is crucial during emergencies”.

On another place, Akcar, Gopalan and Yonder (2012) also stated:

"Disasters increase women's household and care-giving work dramatically for an extended period of time as housing and social infrastructure once destroyed is slowly replaced. They require women to manage displaced households and restore family livelihoods. Yet post-disaster aid efforts generally ignore this reality and target male-headed households as the primary claimants for government and other support. Not only does this approach to aid ignore women's joint claim on family assets, it also ignores the needs of women living apart from male-headed households and is largely indifferent to the incomegenerating roles that women do and must play. These biases substantially undermine prospects for household and community recovery. Gender-sensitive programming is essential during emergency relief. The central aim of disaster relief is to support and rebuild communities; what women do to keep their families and communities together in the critical moments after disaster occurs often is taken for granted. Protocols must be developed that value women's priorities and contributions appropriately.” 
Review of Economics and Development Studies, Vol. 6 (3) 2020, 727-738

Women are described as the sufferers of disaster, and their contributive role in disaster relief work is often unnoticed. Pre-disaster activities are always restricted due to less access to information, resources, and mobility but they play a central role during and after a disaster by rendering relief and care-giving services to the victims. House luggage, children and even animals handling during evacuation is also the responsibility of woman beside the care of old age and disabled.

Plümper and Neumayer (2007) investigated in disasters in 141 countries and explored that deaths in disasters are directly linked with gender differences, power relations and women's social and economic rights provision. Societies where equal rights provision exists, the number of deaths remain same by both sexes. Existing social inequalities bring great causalities i.e. in disasters boys are more preferred for evacuation, food and medicine provision. Studies demonstrate that women and children are 14 times more susceptible towards life threats than men during a disaster.

During the cyclone in Bangladesh in 1991, $90 \%$ were women from total number of 140,000 people who died. More women than men died in heat wave of Europe in 2003. Number of women victims was on increase in France and during the emergency of hurricane Katrina in America. Due to having knowledge of climbing and swimming, it was easier for men to evacuate during disasters in Sri Lanka. Due to the social prejudices and cultural restraints, girls have no access to life saving skills and activities which will increase their susceptibility towards threats. In droughts, women are most suffered population who are responsible for water search and carrying but their water intake ratio goes too less (IUCN Fact Sheet, 2016). In 2015, the first Australian 'Gender and Disaster Taskforce' was established.

Scientists of Macquarie University, Sydney, Australia, conducted a research in 2007 to find out the effects of including native people of communities as participants in planning of how to deal with natural disasters. They found that techniques to cope with natural disasters used by community people were highly effective. They investigated that involvement of community and especially the involvement of women is highly significant in disaster planning activities. Participatory approaches create a sense of ownership, sense of empowerment, sense of cooperation and responsibility in people of community. People themselves are better planner of their situations. By inclusion of female participants in emergency planning, a sense of encouragement discovered the powerful problem solving and needbased mechanism to deal with disasters.

Former Director of the United Nations International Strategy for Disaster Reduction, Salvano Briceno said that community suppleness against disasters cannot be achieved without the full participation of women in leadership, planning and decision making. Still there are communities, where female participation is not encouraged and results in great number of deaths in disasters.

Fothergill in 1996 wrote that due to the inequality in social structure, in many developing countries women and children are most vulnerable population in natural disasters as compared to men 


\section{Figure-3}

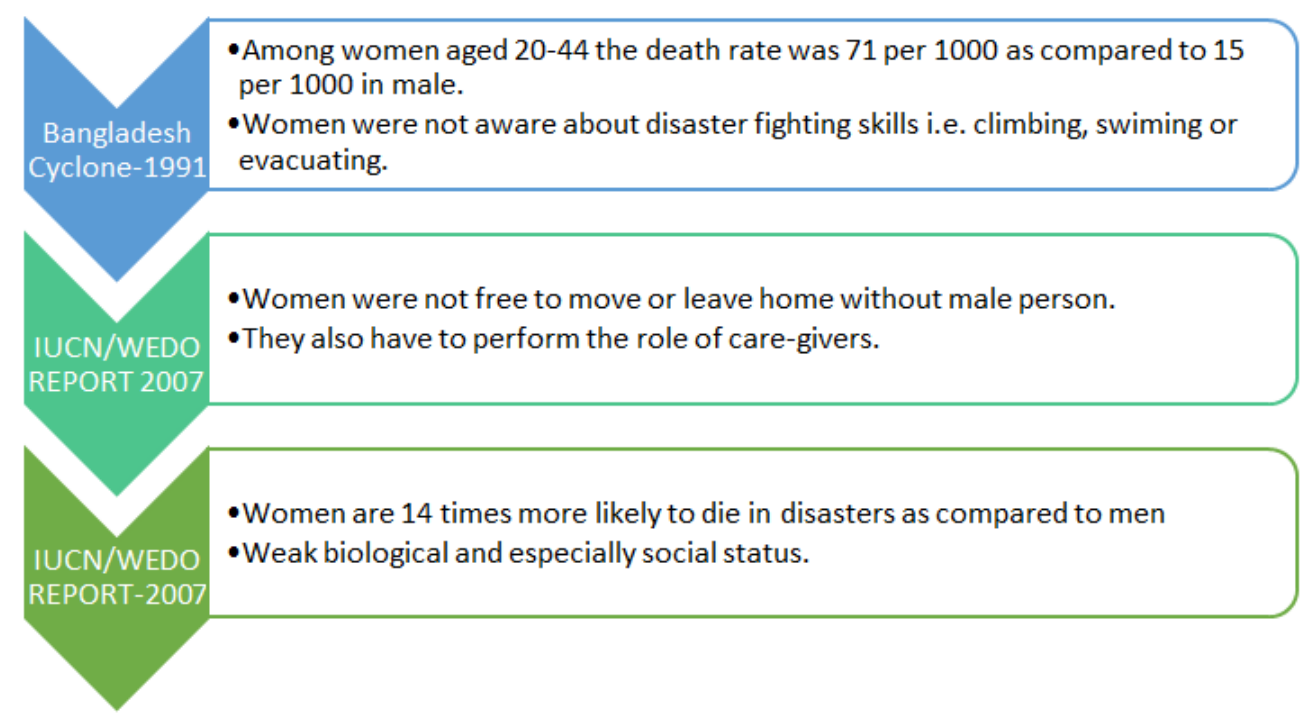

This slower recovery has been attributed to the fact that women have a tendency to have minus access to assets provided during emergency and recovery periods (Khondker,1996). Other societal factors used to explain women's greater vulnerability to disasters are their role as caregivers and their lack of mobility (Fothergill, 1996).

The women were facing issues / challenges during the disaster situation such as non-availability of sex disaggregated data, cultural restrictions on mobility, children and luggage dependency, protection issues in relief camps, unequal service delivery, access to microfinance, limited access to information \& knowledge / preparedness, non-availability of female doctors in relief camps, no participation in decision making and planning, non-availability of recreational / educational activities for girls in relief camps, absence of code of conduct during evacuation, no separate relief services points, inadequate / separate washrooms and feeding areas, no re-organization of women headed households, evacuation challenges, inadequate provision of washing services, no sOPs and policy inclusion.

The issues / challenges faced by the children during the disaster were absence of SOPs on children needs and concerns, children need's inclusion in National and Provincial plans, abuse, exploitation and kidnapping, no access to information and knowledge/preparedness, not in a position of decision making and mobility, non-availability of high energy food, absence of child protection mechanism, non-availability of educational and psychological services, non-availability of recreational services, non-inclusion of children's needs in National plans, policy and legislation, health, nutritional, sanitation and hygiene issues, communication issues, and issue of registration of lost/shifted children.

\section{International Legislation on Women \& Children Based Disaster Risk Management:}

The following international legislations ensure the rights of women and children in disaster situation:

- CEDAW

- UNCRC

- Declaration on the Protection of Women and Children in Emergency and Armed Conflict-1974 (General Assembly resolution 3318 (XXIX) of 14 December 1974) 
Review of Economics and Development Studies, Vol. 6 (3) 2020, 727-738

- The new Sustainable Development Goals (SDGs), and the comprehensive sustainability agenda, go much further than the Millennium Development Goals, addressing the worldwide need for progress for all people.

* $5^{\text {th }}$ Goal is Gender Equality

* $10^{\text {th }}$ is Reduced Inequalities

* $13^{\text {th }}$ Climate Action

- Hyogo Framework for Action 2005-2015: Building the Resilience of Nations and communities to disasters

- Sendai Framework for Disaster Risk Reduction 2015-2030

- UNISDR (United Nation office for disaster risk reduction)

- Yokohama Strategy and Plan of Action for a Safer World-1994-(UN guidelines for natural disaster prevention, preparedness and mitigation)

- Beijing declaration and platform for action-1995

\section{Gender \& Children Based Legislation on Disaster Risk Management in Pakistan:}

The following all policy documents and laws in Pakistan emphasize on Disaster Risk Management by community participation and reveal that vulnerabilities can be reduced by focusing on vulnerable groups of people. The needs and concerns of vulnerable groups are prioritized on equal basis in preparedness and community inclusion level and at rescue, relief and recovery level.

- National Disaster Risk Management Framework of Pakistan-2007

- Social Protection Strategy of ERRA

- Gender policy for earthquake affected areas

- National Disaster Management Plan -2012-2022

- National Disaster Risk Reduction Policy

- National Gender \& Children Cell Framework 2013-16

- The National Calamities (Prevention and Relief) Act 1958

- Emergencies Services Ordinance 2002

- Child Protection Welfare Act 2010-KPK

- PDMA Policy

- National Disaster Management Act-2010 makes specific references to special provisions for vulnerable groups:

- Section 11: Guidelines for minimum standards of Relief,

- Sub-Section (b): special provisions to be made for vulnerable groups.

- Section 37: Prohibition against discrimination: while providing recompense and relief to victims of the disasters, there should be no discrimination on the grounds of sex, caste, community, descent, or religion.

UNICEF has established Gender \& Child Cell (GCC) in NDMA, PDMAs and DDMAs to provide strategies and line of action to all concerned stakeholders to minimize the vulnerability of women and children in disasters.

\section{Women \& Children Based Disaster Management Services in Developed Countries:}

The following organizations and agencies are providing their services for crisis and disaster 
Review of Economics and Development Studies, Vol. 6 (3) 2020, 727-738

management:

- $\quad$ Red Cross and Federal Emergency Management Agency (FEMA), USA

- Emergency Management Australia.

- Public Safety Canada

- National Crisis Management Centre (NCMC) (Newzealand)

- Federal Agency for Technical Relief, THW (Germany)

- Agency for Support and Coordination of Russian Participation in International Humanitarian Operations" (EMERCOM Agency) of the Ministry of Civil Defense and Emergencies of the Russian Federation.

- Civil Contingencies Secretariat (UK)

USA has developed online system of searching lost children/persons, searching shelter and to volunteer yourself, flood insurance is provided, gender \& child-based doctors, food, planning, policy and training is provided, gender based equality in movement, access to information and knowledge is ensured, focus on WASH services, women protection \& priority in evacuation, gender disaggregated database management and registration of women headed households is provided.

\section{Women \& Child Based Disaster Management services in Pakistan:}

After 2015, the Government has specifically ensured in disaster stricken areas the provision of child \& women sensitive food hampers, priority to women \& child in evacuation/rescue, separate temporary toilets for women, high energy biscuits, diets and milk for children, availability of female doctors, recreational activities/sports, toys and playing item for children and dresses for women, temporary schools in relief camps, district administration and officer's presence for child and women protection and availability of hygiene kits.

\section{Gender Based Disaster Management Needs:}

There is a dire need to consider gender-based specific needs in the whole cycle of disaster management. Gender-based Disaster Risk Reduction (DRR) and Disaster Risk Management (DRM) trainings shall be conducted at Provincial (PDMA) as well as District (DDMA) level. Women should be equipped with emergency services, skills and proper awareness about life saving skills at Local level. Proper early preparedness and training is tool which can reduce the magnitude and vulnerability of hazards at any level. Beside the suppressed socio-economic status of women, emergency preparedness, evacuation training and life safety knowledge must be communicated to women at local level by involving lady teachers, Lady Health Workers (LHV) and other community key professional women.

Policy and planning should be based on empirical evidence of research. There is need to use gender lens while reporting the situation and status of vulnerability of any area. Women special needs and issues be considered in physical research and that research can prove a base for further policy and planning while including gender sensitivity. Restoration is not only physical but also socio-economic. Many working women become deprived of their outdoor jobs i.e. daily wages, fields work, teaching, nursing etc. or indoor jobs of crafting, sewing \& stitching, and arts. Due to disasters all their productivity and ways of earning come to an end and make them more vulnerable. Alternative economic activities may be extended in relief camps for the best use of their skills and fearful mind. Women should be priority in evacuation in rescue teams as they are physically sensitive and weak then man. Women are more sensitive to exploitation, harassment and sexual abuse during the calamities. During evacuation and in relief camps, safety and security of women should be a top priority by emphasizing on separate women relief camps with adequate security and protection against wanderers. 
Trustworthy Camp's administration is hired.

It is usually seen that in emergencies either there are no toilets or toilets with common use of both sexes. It can be dangerous in results. Gender based separate toilets be arranged in relief camps by analyzing the special needs and sensitive position of women. Relief camps may be preferred to be organized where separate bathroom facility is available. Organization of Gender based separate service centers, so women can also get relief items at equal level, not on the basis of power or dominance. Micro finance services may be initiated by Govt., INGOs and NGOs to alleviate the sufferings of working women, who were engaged in micro domestic economic activities i.e. carpet making, stitching, arts and design, handicrafts, livestock. Women headed household must be included in provision of all services and provisions.

In relief camps after disasters, temporary school camps may be organized so that girl's education may remain continued. Lady Doctors may be appointed in relief camps for injured woman, in order to control diseases as disasters bring diseases and especially for pregnant women. Private areas shall be provided for lactating mothers. All records must be managed for girls who were rescued, evacuated or injured and who were sent to different hospitals by NGOs, INGOs, Government departments or volunteers. Girl's lost ratio and misuse can be minimized in this way.

Post disaster response and recovery information may be provided to women regarding how to manage things, from where to get relief services and how to get compensation services. In evacuation and rescue operation women and girls should be given priority to be evacuated. Under newly established Local Government System, counsellors, nazims and lady workers of community including nurses, teachers and LHWs should be utilized for awareness, disaster preparedness and evacuation related information sharing purpose. Women headed household should be registered for compensation services. SOPs and policies should be formulated covering all above-mentioned points while having support with legislation. Annual Contingency plans may address the specific needs of women in context of gender.

\section{Child based Disaster Management Needs:}

Children are more vulnerable to violence, neglect, abuse and exploitation so their specific needs must be addressed in DRR, DRM and contingency plans. Children headed household must be included for humanitarian services. Children may be trained for disaster preparedness and response by Girls guide and boys scout services. Children need more balanced and healthy food for their growth in early stages so high energy biscuits, diets and sufficient milk packets may be included in relief services. Child's mind is more sensitive to bear any shock. All disasters, especially earthquakes lead toward emotional instability, psychological stress and fear. Psychological relief by counseling and game therapies must be provided to children. Child protection is an important issue during and after disasters as they are weak and have not sufficient knowledge of world (Cognitive development). Kidnapped, abused and misplaced children in disasters are much common phenomenon. A special focus should be poured on child protection and security. Social welfare Department in collaboration with Child protection Bureau should establish child protection centers in disaster areas to find and register lost children, also to protect them from evil minded persons and to search and handover them to their parents. Otherwise, they should be kept in Social welfare institutions of Children welfare.

Temporary educational camps may be organized in relief camps so that children's education may remain continued and also they can turn their minds from destruction. Healthy recreational activities and sports may also be organized in camps so that children can get relief from shock of disasters. 
According to international legislations, child sensitive disaster laws may be formulated in policy context. Children are more sensitive to diseases as disasters bring polluted environment and children have weak defense system against diseases. Child specialist may be there for regular check-ups. WASH service's (water, sanitation and hygiene) focus should be on children, who are more vulnerable to diseases. Minimum one chapter regarding Disaster Awareness shall be included in primary and secondary level curriculum.

Hygiene conditions may be considered as disasters bring diseases due to damaged infrastructure, dust, no sanitation, infected water and food. In evacuation process, children may be evacuated on priority as they have low capacity in decision making and movement. All transported children to hospitals or other relief camps and places may be registered to avoid kidnapping, misplacement and abuse. Communication assistance may be provided to children whoever requires it. Incorporate childhood psychosocial recovery by school recovery programs. Moreover, provide healthy environment and perform interventions to minimize pediatric psychological trauma.

Practical Gender Needs and Strategic Gender Needs must be considered in all plans and policies. Without these precautions \& measures, it is understood that primary emergency brings the secondary emergency (Figure-4).

\section{Figure-4}

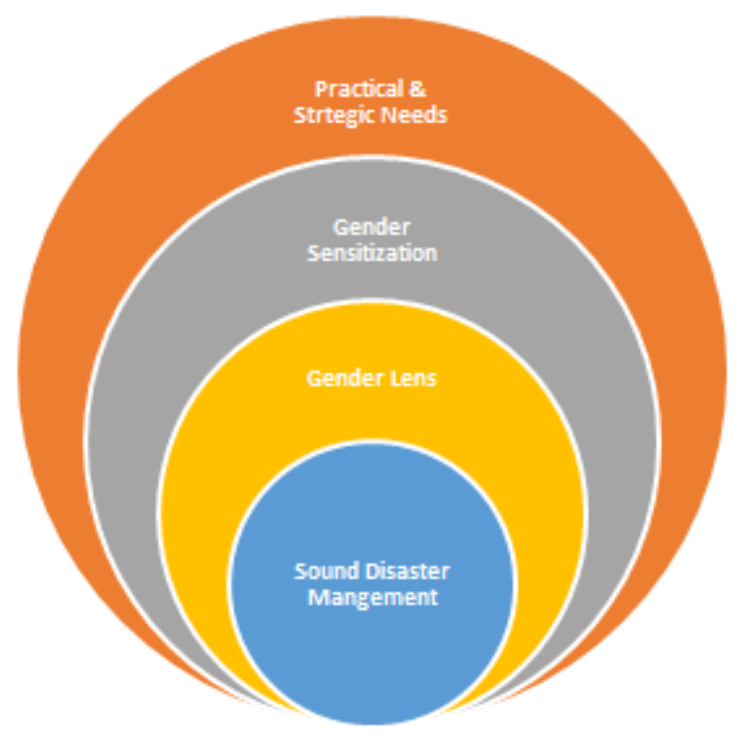

\section{Application of Fields of Social Work in Disaster Management:}

The Figure- 5 shows the roles and services can be provided by the social workers for disaster management at micro and macro levels, as social work education equip the professional social workers with all the requisite skills and knowledge that how they can support and rehabilitate disaster stricken communities, specially women and children. 
Figure-5

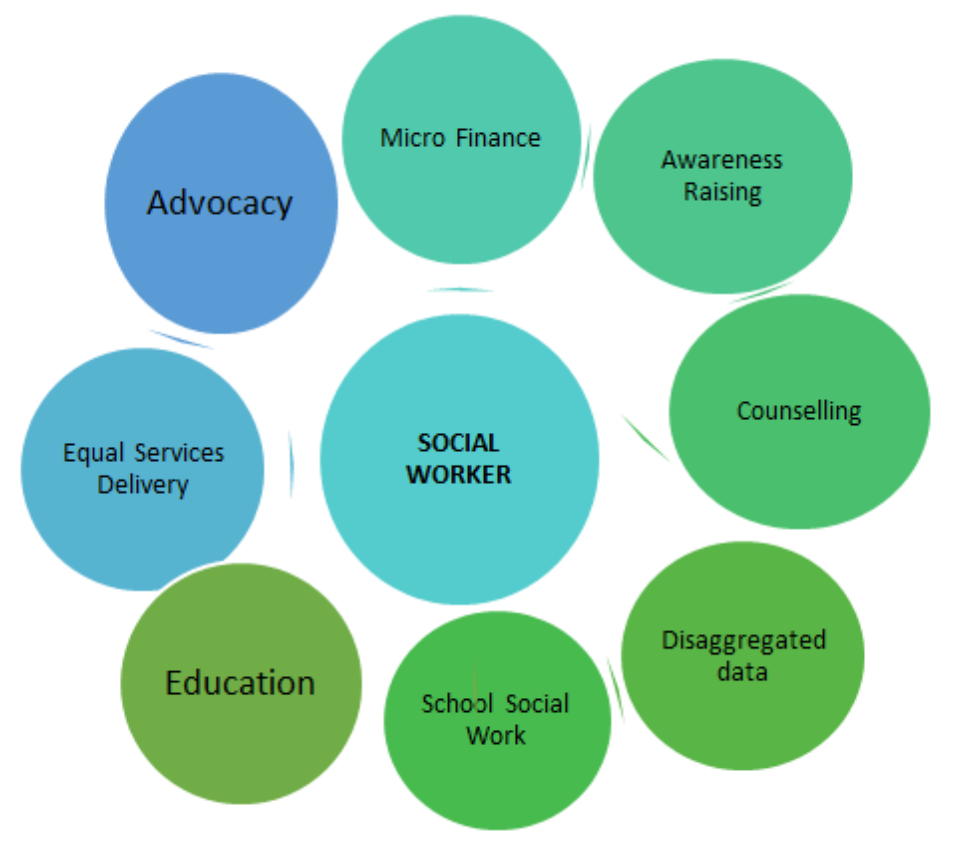

\section{Conclusion}

Our plans and policies must aim at prioritizing and mainstreaming gender and integrating the concerns and needs of children and socially marginalized segments of society in humanitarian response and crises management. All interventions and policy initiatives must be gender \& child sensitive. In whole cycle of disaster management, gender lens may be used in access, opportunities, resources, utilization and benefits. Sensitization is required at individual, institutional and system level.

\section{References}

American Red Cross. (2009). "Preparedness Fast Facts: Emergency-Specific Preparedness Information". America.

Anderson A.William. (2000). Women and children facing disaster. World Bank: New York.

Baig, Fatima.(2014), “National Policy Guidelines on Vulnerable Groups in Disasters”,Bestlink International, NDMA, Islamabad, Pakistan.

Ben Wisner et al., (2004). At Risk: Natural Hazards, People's Vulnerability, and Disasters, $2 d$ ed. London: Routledge.

Brenda Phillips, Maureen Fordham (2010). Introduction in Social Vulnerability to Disasters, New York: CRC Press.

Bullock A. Jane, Haddow D. George, Coppola P. Damon (2011). Managing children in Disasters, New York: CRC Taylor \& Franics Group.

Elaine Enarson, Betty Hearn Morrow. (1998). The Gendered Terrain of Disaster. Santa Barbara: Praeger/Greenwood.

Enarson, E. (1998). Through women's eyes: A gendered research agenda for disaster social science.22 (2):157-73.

Fothergill, A.(1996). "Gender Risk and disasters". International journal of emergencies and disasters. 14 (1):33-56.

Khondker, H.(1996). Women and floods in Bangladesh. International journal of mass emergencies and disasters. 14(3) 281-92.

"National Policy Guidelines on Vulnerable Groups in Disasters, NDMA Pakistan. Retrieved fromhttp://www.ndma.gov.pk/new/Documents/gcc_policy.pdf 
Ole Larsen, Julien Oliver and Erickson Casiles Lauza.(2014), "Developing a Disaster Risk Insurance Framework for Vulnerable Communities In Pakistan”. United Nations. 16-05-2014- UN). Oxfam GB.(2004) Gender Standards for Humanitarian Responses. London: Oxford.

Russell R. Dynes. (1994). Community Emergency Planning: False Assumptions and Inappropriate Analogies. International Journal of Mass Emergencies and Disasters. Vol. 12. pp. 142. 